\title{
ОСОБЕННОСТИ НУТРИТИВНОГО СТАТУСА МАЛЬЧИКОВ-ПОДРОСТКОВ С КОНСТИТУЦИОНАЛЬНОЙ ЗАДЕРЖКОЙ РОСТА И ПУБЕРТАТА
}

\author{
К.А. Чередникова, Н.Ю. Филина, Н.В. Болотова, Е.С. Сафронова \\ ФГБОУ ВО «Саратовский государственный медицинский университет им. В.И. Разумовского» \\ Минздрава России
}

\begin{abstract}
АКТУАЛЬНОСТЬ. Длительный транзиторный дефицит половых гормонов у пациентов с конституциональной задержкой роста и пубертата (КЗРП) оказывает скрытое негативное влияние на процессы роста и все виды обмена веществ в организме, что является предиктором формирования метаболических нарушений.
\end{abstract}

ЦЕЛЬ. Изучить особенности нутритивного статуса пациентов с конституциональной задержкой роста и пубертата.

МАТЕРИАЛЫ И МЕТОДЫ. Обследованы 100 мальчиков-подростков 15 лет, из них - основная группа ( $\mathrm{n}=70)$ - мальчики с КЗРП и группа сравнения $(\mathrm{n}=30)$ здоровых подростков того же возраста. Оценены клинические данные: SDS роста, SDS ИМТ, орхиометрия. Проведена биоимпедансометрия с оценкой жировой (ЖМ), активно-клеточной (АКМ), скелетно-мышечной (СММ) и тощей массы (ТМ). Оценены лабораторные данные: биохимический анализ крови: общий белок, альбумины, креатинин, холестерин и его фракции (ЛПВП, ЛПНП), гормональный профиль: гормональный профиль тестостерон, ЛГ, ФСГ. Результаты представлены в виде медианы (Ме) и квартилей ([Q1; Q3]), для оценки значимых отличий использован критерии Манна-Уитни, проведен корреляционный анализ.

РЕзУЛЬтАТЫ. При оценке физического развития Ме SDS роста в основной группе составила - 2,3 [-2,5; -2,0], в группе сравнения $1,2[-0,8 ; 1,9](p=0,003)$. Объем гонад пациентов с КЗРП составил $3,0[2,0 ; 3,0]$ мл, в группе сравнения - 16 [12;18] мл. Показатели упитанности мальчиков с КЗРП достоверно отличались: у 58\% (41) пациентов наблюдалась белково-энергетическая недостаточность легкой степени и у 10\% (7) пациентов средней степени тяжести, Me SDS ИMT составила $-1,32[-1,8 ;-1,1]$ и $0,93[-0,1 ; 1,6]$ в основной и группе сравнения соответственно $(p=0,001)$. По данным биоимпедансометрииудетей сКЗРПна фонесниженияпоказателей СММ $(5,8[5,4 ; 6,0]$ кг/м² относительно

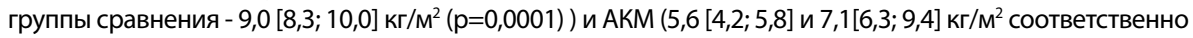
$(p=0,001))$ выявлено достоверное повышение ЖМ $(5,3[3,7 ; 5,4]$ и $3,55[2,3 ; 3,9]$ кг/м² соответственно), что свидетельствовало о наличии скрытых метаболических нарушений. При оценке биохимических показателей крови, характеризующих нутритивный статус, у пациентов с КЗРП уровень общего белка составил 74 [72; 74,4] г/л, что не имело отличий от показателей группы сравнения (71 [68; 73] г/л). По уровню альбумина и креатинина отклонений так же не выявлено. При оценке липидного спектра у 18\% (13) подростков с КЗРП выявлена гиперхолестеринемия, у 23\% (16) отмечена дислипидемия, из них в 13\% (9) случаях наблюдалось повышение ЛПНП, в 10\% (7) - снижение ЛПВП). Отклонения нутритивного статуса пациентов с КЗРП ассоциированы с андрогенным дефицитом: Ме тестостерона в основной группе была ниже в 18 раз показателя здоровых сверстников и составила 0,98 [0,69; 3,0] нмольไл. При оценке корреляционных взаимосвязей показателей гормонального и метаболического профиля пациентов с КЗРП получена прямая связь средней силы между тестостероном и АКМ $(r=0,52 ; p=0,001)$, тестостероном и СMМ $(r=0,58 ; p=0,001)$, и патологическая прямая связь тестостерона с ЖМ ( $r=0,51 ; p=0,001)$, отрицательная слабая связь с уровнем холестерина $(r=-0,38 ; p=0,001)$, что подтверждало риски формирования метаболического синдрома у этих пациентов.

\section{выводы.}

1. Особенностями нутритивного статуса пациентов с КЗРП является выраженный белковоэнергетический дефицит с признаками пресаркопении по показателям АКК и СММ; повышение доли ЖМ указывает на скрытые метаболические расстройства.

2. Выявленная патологическая направленность корреляций между тестостероном, жировым компонентом и холестерином; нарушения жирового обмена в виде гиперхолестеринемии и дислипидемии на фоне увеличения доли жировой массы указывают на формирование метаболического синдрома у пациентов с конституциональной задержкой роста и пубертата. 